\title{
Activating moral imagination: EXPOSED 2013 as a fourth generation faith-based campaign?
}

\author{
Bowers-Du Toit, Nadine \\ Stellenbosch University \\ nbowers@sun.ac.za \\ Forster, Dion \\ Stellenbosch University
}

\begin{abstract}
David Korten proposes a Fourth Generation approach (1990) to development that is value driven and sees social movements take centre stage in promoting a more just global society. Theologian Ignatius Swart (2006) has argued that Korten's approach holds significant value for civil society role players such as the church, whose valuedriven agenda may serve to resist common values expressed by the powerful in society. Recently, the EXPOSED 2013 campaign has emerged as such a Christian social movement, seeking to mobilise up to 100 million Christians globally to take action against corruption. Using social media and church networks at all levels it aims to petition the G20 for more open tax regimes and greater transparency in international money flows to combat bribery and tax avoidance. This article documents and critically analyses the EXPOSED 2013 campaign through the lens of Korten's Fourth Generation in dialogue with Swart's faith-based analysis of Korten's work.
\end{abstract}

Keywords

Religion and development, Public theology, David Korten, Fourth-generation approach, Social movements, Online social movements, Corruption

\section{Introduction}

The Christian scriptures place a significant focus on issues of social justice, as a result most churches, ecumenical movements and communions show a strong commitment to issues of social justice in their work and witness (Palmer \& Burgess 2012:64). ${ }^{1}$ Prominent Christian Theologians,

1 Theologically the debate has focussed on the relationship between evangelism and social action in the ministry of the church. Some have contended that the primary role 
such as Jürgen Moltmann (Moltmann 2006:24-29) and Stanley Hauerwas (Hauerwas 2014:80-83), contend that the very nature of the Christian faith, with its emphasis on justice, has clear social and political ramifications. The latter has been embodied over the past century through Christian's resistance to injustice and inequality through the Church's active engagement in social movements such as the Civil Rights movement and anti-Apartheid struggle.

David Korten's fourth generation approach holds promise for value-driven global civil society role players, such as religious groupings and movements, since they are motivated by a vision of a just society. The latter has been argued by scholars such as Ignatius Swart, who have further emphasised the possibilities of the church's engagement as a fourth generation actor within global civil society discourse. It is important to note that both Korten and Swart note the possibilities offered by new communication technologies, and the networks they both utilise and create, in activating possible social change. It is into this milieu that the EXPOSED campaign was birthed. EXPOSED - Shining a light on corruption, is a limited duration global Christian campaign that seeks to address the problem of corruption on a global and national scale. This paper will, therefore, consider whether EXPOSED functioned as a faith-based fourth generation movement.

In order to fulfil this task we shall discuss the rise of online social movements (such as EXPOSED), as well as the effect of faith and religion on

of the church is to bring persons to faith (evangelism), while others have contended that the primary role of the church is to work for a world that reflects the values of the Kingdom of God (such as justice, equality, peace and flourishing). It is contended that faith is more credible when the church has a consistent witness that fosters the good of all in society. One of the better known recent examples of such an integration of evangelical commitment and social justice is to be found in the life and witness of Dietrich Bonhoeffer (Palmer \& Burgess 2012:64-65). Living as a Christian in Germany during the rise of the Nazi regime Bonhoeffer found it more and more important to take a stand against social injustice, particularly the injustice that was metered against Jews, as a witness to the core of his faith conviction. This ultimately led to his imprisonment and death at the hands of the Nazis. Bonhoeffer followed in a long line of martyrs who throughout history have sacrificed their lives for the transformation of society because of their faith convictions. He also serves as a precursor to the liberation theologians that emerged in Latin America, Africa and Asia in the decades that followed the 1940's. This approach to theology was strongly formed by socio-economic and socio-political issues. It focussed on matters such as race, gender, and economic status and sought to hold a preferential option for the poor and disenfranchised in society. Among the better-known names in this field are persons such as Gustavo Guitierrez, Martin Luther King Jr, and Archbishop Desmond Tutu. 
fourth generation movements. EXPOSED will function as a case study for the investigation. The case study will sketch a theological and an historical overview of the formation and functioning of the EXPOSED campaign from its inception to date. In addition to the previously stated objective, it is also intended that that section of the paper will provide an insight into the theological rationale that informed the founding and development of the campaign and its activities.

We shall draw upon official documents (such as newsletters, brochures, press statements and minutes of Steering Group ${ }^{2}$ and Working Group meetings), as well as interviews to compile the necessary information for the case study.

In conclusion we will critically analyse and evaluate the EXPOSED campaign as a fourth generation actor.

\section{The rise of online social movements}

Although social scientists have studied the topic of social movements for many decades, there has been an upswing in interest over the past few years as we have viewed sweeping changes occurring through various social movements via the use of the Internet. Indeed the emergence of "e-movements", "e-protest" or "e-activism" have "signified the importance of the Internet as an organisational and mobilization vehicle for those engaged in social change" (Hara \& Huang 2011:489). Online social movements have certainly provided the opportunity for citizens to participate in political decision making from which they may have previously been excluded or to potentially raise civil awareness with regards to these processes. The Internet has also been considered a cost effective medium for activist groups who

2 Governance of the EXPOSED campaign operates at three primary levels. At the highest level is the EXPOSED Trust. This is the legal entity that has fiduciary responsibility for the campaign (audited financial statements, contractual agreements with staff and suppliers etc.) However, the primary responsibility for the shaping and oversight of EXPOSED is undertaken by an Executive board called the Steering Group. This group is comprised of the Chairman of EXPOSED and at least one representative from each of the founding partner organisations. Selected staff of the EXPOSED campaign participates in Steering Group meetings to report on various aspects of the campaign. The Working Group handled the operational functions of the campaign, particularly in its early stages. The International Coordinator convened this committee with coopted members from the founding and partner organisations. It reported into Steering Group. 
do not have sufficient capital (Hara \& Huang 2011:497-499). Perhaps most intriguing for this case study is the use of Information Communication Technology (ICT) in the formation of collective identity and solidarity. According to Hara \& Huang (2011:500), the Internet "could be considered a useful tool to support processes of collective identity construction" an important outcome of social movement mobilisation. In this way a "like-minded" consciousness could be formed, which crosses national and cultural boundaries. Manuel Castells' book Networks of Outrage and Hope: Social Movements in the Internet Age (2012) highlights how that in a Network Society, digital communication provides a mass platform for the "construction of the autonomy of the social actor/s" (Castells 2012:7). He notes that behind mass communication of this nature, lay the power to change power relationships:

By engaging in the production of mass media messages, and by developing autonomous networks of horizontal communication, citizens of the information age become able to invent new programs for their lives with the materials of their suffering, fears, dreams and hopes. They build their projects around shared experiences. They subvert the practice of communication as usual by occupying the medium and creating the message. They overcome the powerlessness of their solitary despair by networking their desire. They fight the powers that be, by identifying the networks that are.

In recent years the use of social networking sites has become a popular means of "online mobilisation". The Arab Spring and Occupy Wall Street best evidence this as documented in Castells' book. It was, nevertheless, a faith based movement that is viewed as one of the first successful online movements. Although Jubilee 2000 began as a faith based grassroots movement it soon formed a broad-based coalition of international aid agencies, which utilised the fledgling Internet (Gordon 2003:162, 163; cf. Barret 2000). Bennet (2005:218) terms Jubilee 2000, one of the first forms of "hyper-organisation" - in other words an organisation which existed as it developed, mainly in the form of "the website, email traffic, and linked cites". Bennet (2005:218) also notes that Jubilee had a remarkable balance of North/South participants and: 
... rejected the formation of an international secretariat at a crucial stage in its evolution, in favour of continued horizontal diffusion of email lists that reach large numbers of Southern organisations with computers, who passed along issues and inputs to their offline constituencies.

He argues that despite critique that may be levelled with regards to North/ South technological inequalities, "Jubilee was not just an organisation enhanced or magnified by the simple application of emails lists - it was constituted by that technology as well as the offline meetings through which its members interacted" (Bennet 2005:219). More recent literature in the field has pointed to the rising importance of blogs and social networking sites (such as Twitter and Facebook) as essential means for social mobilisation (Turner 2013; Hara \& Huang 2011:512). Such tools are well suited to facilitate collective action, which is popularly defined as a joint group activity, which seeks to pursue public good through means such as "voting, lobbying or demonstrating, which occurs on different social bases (class, ethnic group or gender) and focuses on achieving a variety of goals" (Hechter et al in Hara \& Huang 2011:505).

These new means of mobilisation have been noted by a number of international scholars as impacting on political dialogue and discourse and in turn "insuring the instant success of such movements" (Turner 2013:279). In this way, the most recent online social movements through the use of the Internet, have been instrumental in fostering what Turner terms "new models of direct democracy", which are often radical and extra - institutional (Turner 2013:281).

\section{The fourth generation approach and the role of religion}

David Korten's $4^{\text {th }}$ Generation approach to development is one, which forms part of framework of "four historical phases of NGO development activity" (Swart and Venter 2002:51; cf. Korten 1990:115). Although Korten's schema traces the possible development of what he terms the

3 Movements best associated with this type of direct democracy are theoretically labelled as 'New Social Movements' (NSM). It is theorized that such movements are value and identity based (Hara \& Huang 2011:492, 493). 
different "generations" of development from relief and welfare, community development, sustainable systems development through to its fourth generation, which he terms "peoples movements", it should be noted that the fourth generation should not necessarily be lauded above the other approaches in his work. Korten has integrated these approaches within the NGO development debate into a single framework, which in some ways indicate a "definite pattern on evolution in NGO development activity" (Swart 2006:97). Korten, nevertheless identifies in the aforementioned first three strategies, what Swart (2006:132; cf. Swart \& Venter 2002:54; cf. Korten 1990:127) terms an "inadequate mobilising vision," and therefore argues that the paradigm of people-centred development can only become a "dominant global paradigm" of a transformative nature if it influences public consciousness on a national or global scale. In this way the fourth generation approach radicalises the concept of people-centred development as noted by the third generation approach, through its transition into the terrain of social movements (Swart 2006:131). It is important to note that this radicalisation is based on Korten's awareness that in order for NGO's to "think beyond repair work"; there must be recognition of the interdependent nature of systems within global development (Swart 2006:129). The fourth generation approach, although rooted within development discourse, is certainly, at least according to Swart and Venter (2002:51-52), framed within broader discourses on civil society, new social movements and what Korten terms "global transformative politics". In this way the approach offers the potential to provide a particularly useful lens through which to analyse new social movements of the kind which operate on a global scale and which seek to challenge the politics and economics of the global capitalist system ${ }^{4}$.

This framework as clearly situated within the social movement discourse, is according to Korten (1990:124), largely value and vision based. Rather than

4 Swart $(2006: 155,161)$ in fact argues that Korten's framework should be pushed further into the realm of 'wider political discourses of global governance and global institutional and structural transformation.' This is particularly in light of the emergence of transnational social movements who, in their resistance to neoliberalism, have turned their focus on bodies such as the Bretton Woods institutions (Della Porta \& Tarrow 2005:217). It is within this global discourse that Swart (2006:170) emphasises the need for a global and more complex civil society approach, which promotes a 'more effective and deliberate coalition of progressive alternative actors or forces to push forward the true global reach of alternative agendas.' 
being driven by "budgets or organisational structures," such movements are driven by "ideas, by a vision of a better world". New social movements, it is argued by Korten (1995:55), possess the best potentials of civil society to drive social change due to their ability to "rapidly and flexibly network diverse and dispersed individuals and organisations that are motivated by voluntary commitments". Evidence of the latter has been "concretely manifested in the successes of movements in the field of human rights, women, peace and population" and more recently in the Arab Spring and Occupy movement as documented by scholars such as Castells (Castells 2012; cf. Swart \& Venter 2002:55; Korten 1990:124;). It is interesting to note that, all of the most recent new social movements have made extensive use of communication technology, an aspect which one may dare to state was prophetically foretold by Korten in his emphasis on a communication strategy for social movements, which made use of mass media, recorded media, major events, study groups and social networks ${ }^{5}$ (Korten 1990:127). The use of communication technology is particularly powerful when engaging in global transnational transformation of the kind proposed by Korten and as outlined in the next section of this paper.

Within a fourth generation approach, Korten (1990:133) identifies the agenda as transformational in that he notes that the emphasis is on the "transformation of our values, technology and institutions - in both North and South". This transformational agenda, however, may only be successfully advanced through a values based approach, that seeks to conscientise and mobilise public consciousness with regards to a kind of people-centred vision. It is also an agenda, which challenges the dominant institutions and discourses of global society (Korten 1990:123;127; Swart 2006:132). Social movements, Korten argues (1990:24) possess a special quality in that they "move on social energy, more than on money". He notes that it is vision that "mobilises independent action by countless individuals and organisations across national boundaries, all supporting a shared ideal". According to Swart (2006:134) this vision is people-centred in that it represents value and idea centred processes, which are aimed at

5 It should be noted here that Korten was of course not referring to social networking, as we know it today; however, social networks are today of course facilitated in part by social networking. 
the wellbeing of people and in which people becomes the "actual subjects or owners of change".

It is not surprising, then, that Swart (2006) utilises Korten's framework in his analysis of the church's role in society. Although Korten makes no mention of a specific religious group or movement and rather refers to "spirituality," Swart (2006:144) argues that social actors within the religious sphere, such as the church, can best embody what Korten terms "the emergence of an alternative human consciousness". This alternative consciousness is centred on the understanding that the perpetuation of unjust social structures is rooted in the "deeply embedded" egoism and greed of individuals. Korten, therefore, proposes that one of the means to strengthen the human spirit so that these impulses are subverted is through religion. He notes that, "this is perhaps one of the most central of religious missions, and a far worthier challenge for religiously orientated voluntary development organisations than the distribution of charity to the victims of the failures of spiritual teaching" (Korten 1990: 168). Korten's understanding of spirituality is by no means a dualistic one in that, according to Swart (2006:145) it takes on a "distinct socio-political dimension" in engaging with the concept of power. Religion, then, is viewed as a means to concientise power holders through the promotion of values that advance what Korten terms "stewardship responsibility". This consciousness unmasks the egoistic and greedy in human nature and assists the power holders in exercising their power in the interests of the weak and disempowered (Korten 1990:169; Swart 2006:145). Furthermore, Swart (2006:191) ties together various other elements of the church's suitability to engage the fourth generation approach through what Korten terms "key elements of a global transformation agenda". He emphasises the church has always made contributions to the dimensions of lifestyle and family, and through its ideas, ethics and values holds the potentiality to "make meaningful contributions" to the elements of political and economic democratisation. Korten also views religion as contributing to what he terms "the need for reconciliation". ${ }^{6}$ He notes that:

6 Swart (2006:154) notes that Korten argues for the church to be distinctive in its engagement with development issues and argues that in this quest faith based Voluntary 
Religion, which commonly presumes to be society's arbiter of the values that govern human behaviour and relationships, must surely play a central role. While religion is all too often invoked as the rallying cry of the intolerant and hateful in the cause of violence, the basic message of all the world's great religious teachers has been one of love, brotherhood and tolerance (Korten 1990:189).

Another of the key aspects of the fourth generation approach is the role played by voluntary organisations and people's organisations in advancing a transformative people-centred agenda. Swart (2006:192) argues, "the churches are in essence, and at their best, voluntary organisations (VOs) that operate and exist on the basis of the faith and moral commitment of their members. But they can also well be conceived as people's organisations (POs) that are collectively run and owned by their members on the basis of a shared faith and values". Swart also notes "integral to their mission is preparing and sending out their members to live out their faith and values in the world," which ties in with the concept of citizen volunteers. Perhaps most significant is the church's long history, as a value and ideas based institution, of social movement mobilisation ${ }^{7}$. In drawing on Castell's understanding of "resistance identities", Swart (2006:198) identifies the churches (or at least "a segment of the churches") as being strong in, and even having "excelled, as fourth generation actors". He in turn ties this back into the contribution of liberation theology:

Certainly, the message of the theology of liberation and the practices that it inspires should remain a basic point of departure of the churches when faced with the issue of development, particularly the notion of fourth generation development. In fact it should be said that, based on a distinctive theological self-understanding, there can be no other point of departure but the theology of liberation: an unconditional option for the poor, marginalised and oppressed,

Organisations (VOs) could play a key role in 'carrying forward the universal messages of love, brotherhood and tolerance.'

7 Marsh (2005) for example, in his book "The Beloved Community" traces how faith has shaped social justice from the civil rights movement until today, however, there are many other examples throughout history that may be drawn upon. 
for the popular and grassroots movements they represent (Swart 2006:200-201). ${ }^{8}$

It is important to note that although Swart recognises the importance of the local church and certainly positions it as more than a first and second generation actor, he argues forcefully for the church to engage as a civil society actor within "both local and global realities" (Swart 2006:213). $\mathrm{He}$ is particularly critical of the ecumenical movement (as represented by the World Council of Churches), who he argues have failed to critically engage with the "transnationalism and the gross concentration of power under contemporary capitalism" (Swart 2006:214). It should, nevertheless, be noted that one of the most prominent transnational campaigns and movements, which embodies much of what Korten himself envisioned the role of religion and spirituality to be - namely Jubilee 2000 - started as a Christian faith based campaign. Jubilee $2000^{9}$ began as a campaign to address the issue of third world debt, through lobbying for its cancellation. Local churches are cited as being at the heart of this campaign, although Aid Agencies soon formed a broad based coalition at both national and international levels (Gordon 2003:165).

\section{Case study: EXPOSED - Shining a light on corruption}

The first clear explanation of the EXPOSED campaign comes from the campaign Policy Document that was adopted by the EXPOSED Steering Committee on 2 July 2012.

EXPOSED is a global call to action against corruption, which is both a cause and consequence of poverty. It is a response of the Christian Church inspired from the Bible and is committed to promote practical steps for ethical behaviour in business, government, the Church and society as a whole. It aims to position Christians as advocates and practitioners of justice and transformation in the nations we are called to serve (Jackson et al. 2012:1).

8 Swart $(2006: 201,202)$ then proceeds to tie this in to Duchrow's proposal of Ecclesial Base Communities, which although useful at a local church level, is not fully convincing with regards to the new social movement debates - an aspect acknowledged by Swart (Swart 2006:206).

9 It was later re-named "Drop the Debt" and has received widespread recognition for its successful lobbying of what was then termed the G8. 


\subsection{What motivated the formation of the campaign?}

The EXPOSED campaign was launched by a coalition of Christian ministries and organisations. The express intention of the campaign aimed to make a contribution towards the attainment of the United Nations Millennium Development Goals (MDG's). The United Nations gives this summary of the purpose of the MDG's:

The eight Millennium Development Goals (MDGs) - which range from halving extreme poverty rates to halting the spread of HIV/ AIDS and providing universal primary education, all by the target date of 2015 - form a blueprint agreed to by all the world's countries and all the world's leading development institutions. They have galvanized unprecedented efforts to meet the needs of the world's poorest. (“United Nations Millennium Development Goals", 2014)

The founding coalition partners for the EXPOSED campaign share the Biblical concern for justice, which were most clearly expressed in the two primary Biblical references that were used in the campaign:

"He has told you, O mortal, what is good; and what does the Lord require of you but to do justice, and to love kindness, and to walk humbly with your God" (Micah 6.8 NRSV).

“... learn to do good; seek justice, rescue the oppressed, defend the orphan, plead for the widow" (Isaiah 1.17 NRSV).

The basic theological rationale behind the campaign is as follows:

Spirituality and resisting corruption are closely tied together in the Bible where right behaviour is inextricably linked to the worship of God. This shapes attitudes to corruption throughout the Bible (Gooder 2014:2).

This theological conviction is what brought these partners together to try and address the issue of corruption for the sake of the poor. Jim Wallis, one of the early supporters and endorsers of the campaign, summed up the understanding that shaped the campaign intentions as follows:

Many of us feel that our faith has been stolen, and it's time to take it back. In particular, an enormous public misrepresentation of Christianity has taken place. And because of an almost uniform 
media misperception, many people around the world now think Christian faith stands for political commitments that are almost the opposite of its true meaning. How did the faith of Jesus come to be known as pro-rich, pro-war, and only pro-American? What has happened here? And how do we get back to a historic, biblical, and genuinely evangelical faith rescued from its contemporary distortions? That rescue operation is even more crucial today, in the face of a deepening social crisis that cries out for more prophetic religion (Wallis 2006: 3-4).

While the coalition partners were in agreement that a great deal had been achieved towards justice in general, and the MDG's in particular, it was clear that "we cannot deliver on our promises unless we address the issue of corruption head on”. (“About Us - EXPOSED - What's it all about?”, 2013).

The Christian faith is still the largest religious movement in the world ${ }^{10}$ (Jenkins, 2011:2). This constituency was viewed as a powerful force to confront institutions, such as governments, businesses and the Church, as well as individuals, on the issue of corruption. The campaign aimed to bring the discourse around corruption and poverty into the mainstream of the global Church's preaching, theology and action ("EXPOSED: About us", 2014).

Moreover, the campaign recognised that it would be valuable to capitalise on the global interest created by the campaign to empower local action, as well as engage international policy. This rationale is what led to the decision to propose three campaign actions, namely, the singing of the Global Call ("EXPOSED: One in a million", 2014) (intended to engage the G20's policies around tax transparency and international bribery), to participate in a public vigil ("EXPOSED: Global Vigils", 2014) (which had the intention of highlighting the issue of corruption through sermons, prayer gatherings and public meetings), and finally to take some form of

10 'According to the statistical tables produced by the respected Centre for the Study of Global Christianity, some 2.3 billion Christians were alive in 2010, about one-third of the planetary population' (Jenkins 2011:2). 
local action ${ }^{11}$ (the intention here was to make a tangible difference to an issue of local concern).

While the EXPOSED campaign was directed primarily at Christians, its efforts were not restricted to working only with Christian groupings and individuals. The Media Strategy document for EXPOSED indicates that the campaign seeks to engage with, and work alongside "Christians and people of other faiths or no faith" (EXPOSED Steering Group, 2013:1). This attitude is most evident in the partnerships with the United Nations Development Program, as well as the engagement with the G20. However, because of the limited duration of the campaign a decision was made to focus primarily on mobilizing and engaging Christians and Christian groupings as a constituency (EXPOSED Steering Group, 2013:2).

Simply stated, it was a lot less complicated to develop an unequivocal Christian message about corruption, based on the Christian scriptures, than it would have been to try and develop a broader message that would be both sensible and acceptable to persons of other faiths.

\subsection{Campaign goals}

From the very start of the campaign ${ }^{12}$ there was a clear understanding that addressing corruption could contribute towards the ending of extreme poverty. The primary conviction behind this, as is explained above, stems from the Christian understanding that justice is central to the work and witness of the church.

With the exception of Unashamedly Ethical, all of the founding partners of the EXPOSED campaign had worked together on the Micah Challenge's 10.10.10 campaign which had the aim of pressing "for governments to fulfil

11 Naturally the problem of corruption is experienced differently in the different nations and contexts of the world. In some cases corruption is much more common in daily life, such as in countries like Nigeria where bribery for basic services in common. In other countries corruption may be less common in everyday life, however, it may be far more powerful at the level of multinational business deals, or governmental corruption. See the following post for a discussion on this issue, (Le Feuvre 2013). For more information on the EXPOSED toolkits and other resources see, (“EXPOSED: Resources", 2014).

12 The first teleconference meeting of interested parties took place on 15 December 2011. The call included representatives from Micah Challenge International, Unashamedly Ethical, the American Bible Society, British and Foreign Bible Society and the Salvation Army. 
[sic] their promises to halve extreme poverty" as part of the Millennium Development Goals (“Micah Challenge: 10.10.10", 2010). This aim was further developed in the EXPOSED campaign policy document:

We want to shine a light on corruption wherever it is present so that integrity is established or restored in financial and political systems, and resources are shared equitably so that all have the opportunity to flourish (Jackson, Baker \& Forster 2012:1).

In order to achieve this goal the EXPOSED campaign aimed to engage with Christians in 100 countries enabling them to take public action against corruption during the campaign week of 14-20 October 2013 (Jackson, Baker \& Forster 2012:5). The stated intention was to involve approximately 100 million people in these 100 countries to participate in three campaign actions:

- To encourage participants to sign the Global Call to End corruption that will go to the G20 meeting in Brisbane Australia in November 2014 (“EXPOSED: One in a million”, 2014).

- To organise or join a Global Vigil against corruption ("EXPOSED: Global Vigils", 2014).

- To take personal or collective action against corruption, for which three "toolkits" were developed. The toolkits are for youth, Christians in business and Christians in general society ("EXPOSED: Resources", 2014).

The founding members of the EXPOSED campaign were the American Bible Society, the British and Foreign Bible Society, Micah Challenge International, the Salvation Army, Unashamedly Ethical and the World Evangelical Alliance. In August 2013 the World Council of Churches ("World Council of Churches", 2013) also became an official partner of the campaign.

The campaign was publically launched in London, UK, at the Houses of Parliament at an event hosted by Lord Paul Boateng on the $11^{\text {th }}$ of October 2012. A second global event took place in Cape Town, South Africa, on the $11^{\text {th }}$ of March 2013, where the "toolkits" mentioned above were presented to the public and made available on the EXPOSED campaign website 
(Forster 2013). These events set in motion the public work of the campaign to develop resources, build partnerships with Churches, organisations and individuals towards the campaign week of 14-20 October 2013 and beyond that to presenting the Global Call to the G20 meeting in November 2014.

During the campaign a total of 153 countries were involved in public events. Many of these "vigils" were registered on the EXPOSED campaign website, the included a 1000 thousand strong march against corruption in Cape Town (Stewart 2014), a Lent Bible study series called 30 pieces of silver that was produced by the Bible Society and used throughout the world (Rounds 2014), letters to ambassadors ahead of the G20 meetings in Australia (Jackson, 2014a), a meeting of 200 Christian leaders in the Republic of Benin to take a stand against corruption (Jackson, 2014b), an open letter from campaigners in Malaysia to their Prime Minister ("EXPOSED: Blog", 2013), an act of public witness and engagement with the state in Nepal (KC 2014), prayer gatherings in Toronto, Canada (MacMillan 2013), and a service of public witness at St Paul's Cathedral in London (Cowling 2013). To date a total of 75000 persons have signed the "Global Call" to end corruption. When the campaign was first launched the organisers had intended to try and gather 1 million signatures for the "Global Call" to end corruption. Sadly this figure was not achieved. In large measure this was due to naiveté - they simply had no idea how people would respond to that particular campaign action, and how difficult it would be to gather signatures on a public list. People in less corrupt countries felt that corruption was not their issue and so didn't think it was necessary to sign the "Global Call", while people in highly corrupt environments faced massive social, economic and personal consequences if their names were publicly traceable to an anti-corruption campaign. Thus two of the three campaign goals were surpassed (the overall number of participants, and the number of participating countries). However, the Steering Group decided to aim for 100 thousand signatures to the "Global Call" before the G20 meeting in November 2014.

As far as we have been able to ascertain through our research of historical records there has never been a movement of this kind with as wide a reach and as much participation in history. 
Without a doubt this campaign would not have been nearly as successful or wide reaching 10 years ago. The proliferation of the Internet, even in developing world contexts, made mobilization and information sharing possible at great speed, at a low cost and with relative ease.

\section{EXPOSED as a faith-based fourth generation approach?}

One of Korten's key identifying characteristics of fourth generation actors are that they are global in reach and attempt to confront the global capitalist system. EXPOSED's scope was certainly global in that one of its goals was to reach Christians in a 100 countries throughout the world to lobby the G20 in taking the issue of corruption more seriously. Furthermore, it is clear that much like the Jubilee 2000/Drop the Debt campaign, there was a distinct recognition of the importance of the campaign being driven both in and by both North and South. A range of national and global events are evidence of this in that meetings, marches and prayer gatherings where held from Cape Town, Benin, Malaysia, Nepal to Canada and the UK. The global reach of the Internet of course facilitated the latter and Korten's vision that the new social movements will make extensive use of communication technologies is no more evident than in this campaign. The newer social media platforms, such as Twitter, Facebook and YouTube were used extensively by EXPOSED both as a direct lobbying tool and as a means of communication around regional, national and grassroots events. In this way the campaign utilised the existing collective identity (namely the Christian faith) and sought to build through social networks, what has been termed "like minded consciousness" around a justice issue in order to mobilise this constituency. It is also evident that, like Jubilee 2000/Drop the Debt, it was not only constituted by the Internet, but also by "offline" meetings. This was further enhanced by the fact that the partner organisations, which formed the initial network, also used their reach and as well as websites and social media platforms to spread the message.

The campaign makes a clear connection between poverty, inequality and corruption and in so doing directly confronts the greed of the capitalist system though addressing both international policies and local collusion with a system that has the potential to perpetuate injustice. Although their approach can by no means be classed together with more radical movements 
such as Occupy in their critique and methods of confrontation, they do espouse a "transformational agenda" and utilise lobbying tools such as marches and petitions to drive this. This agenda is furthermore advanced by what Korten identifies as a "values and vision based" approach, which is rooted in a Christian vision of justice and given voice by their references to key biblical texts. As the sacred texts of the Christian church, it is these kinds of texts that are often used by theologians and clergy in order to activate the prophetic imagination of Christians and in this way conscientise and mobilise consciousness around issues such as those addressed by the campaign. This is confirmed by the stated rationale of the campaign that "spirituality and resisting corruption are closely tied together in the Bible where right behaviour is inextricably linked to the worship of God. This shapes attitudes to corruption throughout the Bible" (Gooder 2014:2). It is such rationale that in turn links back to Korten's (and Swart's) argument of religion as a possible means to confront the perpetuation of unjust social structures. Furthermore, this campaign sought to confront exactly that which Korten identifies is one of religion's key tasks which is to unmask the egoistic and greedy in human nature and assist the power holders (in this campaign bodies such as the G20 and even businesses on grassroots level) in exercising their power in the interests of the weak and disempowered (Korten 1990:169; Swart 2006:145).

It is interesting to note that the campaign utilized what may be termed an "outside-in" approach in that it sought to engage the G20 at a macro global level as well as local congregants in their roles within business and society. In this way Swart's concern that the church be both a fourth and third generation actor is evidenced. Congregations and Christians in their individual capacities were encouraged to be part of widespread prayer vigils and were provided with "toolkits" and bible study materials (which could be used within a congregational context) that attempted to enable them to think through their role as Christians in society. In this way the commitment of their members is activated. Although it was originally networked through 5 founding members - World Evangelical Alliance, World Council of Churches, Unashamedly Ethical, Bible Society and Micah Challenge - many of these organisations are themselves networks at best and may be seen as operating as PO's in their own right. At the same time, however, the campaign itself may even be viewed as a 
PO (People's Organisation) as its ultimate aim was to build partnerships and networks that would take ownership of the vision and carry the anticorruption message to local, regional, national and global levels. Much like other successful new social movements that were directly rights based, EXPOSED was therefore able to "rapidly and flexibly network diverse and dispersed individuals" who are "motivated by voluntary commitments". This is unsurprising if one considers the fact that Swart in fact links in the suitability of the church to the fourth generation exactly because "integral to their mission is sending out their members to live out their faith and values in the world". It is important to note that this campaign was largely driven by what may be considered the evangelical church (and traditionally more socially conservative arm of the church) and, therefore, Swart's critique of the ecumenical movement (and the WCC) may still hold water.

One could question whether a limited duration campaign, such as EXPOSED, could be termed a new social movement as the on-going impact of the campaign will need to be evaluated at a future date. Perhaps this is pushing the concept too far, although it is clear that it operates within a clear network of actors and in terms of its characteristics it may well be termed a fourth generation actor. Its brand of "e-activism" remains rooted in the continuing work of its network partners (POs' and VO's), especially that of Micah Challenge International and Unashamedly Ethical, which despite the end of the campaign continue to mobilise Christians in this regard. Moreover, the lessons learnt from EXPOSED can be insightful for future campaigns of this nature and scope.

\section{Conclusion}

The EXPOSED campaign is the largest and most significant campaign of its type to date. It was able to mobilize an unprecedented number of persons across the world in a short space of time, to witness and act against corruption; however, its true impact is difficult to measure. While the Christian motivation for justice is a primary theological motivator that has contributed towards the success of the campaign, the value of the Internet and communication technologies - such as websites, blogs, email and social media - cannot be discounted. Korten's argument of the possibility inherent in fourth generation actors is, therefore, certainly relevant in 
analysing a faith-based campaign with its strong value and vision driven agenda and use of new communication technologies. It is perhaps too early, however, to determine whether the network created by the EXPOSED campaign may be fully termed a "new social movement" as this may only become evident as its trajectory is traced within the continuing work of its partners.

\section{Bibliography}

Barrett, M \& Jubilee 2000 Coalition 2000. The world will never be the same again. London: Jubilee 2000 Coalition.

Beek, KA 2000. Spirituality: a development taboo. Development in Practice, 10( 1): 31-43.

Bennet, WL 2005. Social Movements beyond borders: understanding two eras of Transnational activism. In Transnational Protest and Global Activism: people, passions and power, edited by D Della Porta and S Tarrow. Oxford: Roman and Littleman.

Carbonnier, G 2012. Religion and Development: reconsidering secularism as the norm. Boston: Leiden.

Castells, M 1996. The Rise of the Network Society. Oxford: Blackwell.

Castells, M 2012. Networks of Outrage and Hope: Social Movements in the Internet Age. Cambridge: Polity Press.

Cowling, F 2014. EXPOSED: Blog. The bells of St Paul's Cathedral rang out in the heart of the city of London [Online]. Available:

http://www.exposedcampaign.com/blog/14 [2014, April 14].

EXPOSED: About us. 2014. EXPOSED: About us [Online]. Available: http://www.exposedcampaign.com/about [2014, April 16].

EXPOSED: Blog. 2014. Open letter Malaysia's Prime Minister [Online]. Available: http://www.exposedcampaign.com/blog/63 [2014, April 16].

EXPOSED: Global Vigils. 2014. EXPOSED: Global Vigils [Online]. Available: http://www.exposedcampaign.com/prayer-vigils [2014, April 16]. 
EXPOSED: One in a million. 2014. EXPOSED: One in a million [Online]. Available: http://www.exposedcampaign.com/one-in-a-million [2014, April 16].

EXPOSED: Resources. 2014. EXPOSED: Resources [Online]. Available: http://www.exposedcampaign.com/resources [2014, April 16].

EXPOSED Steering Group. 2013. 9 EXPOSED2013 Media and Communications Strategy April - October 2013. Cape Town. Unpublished minutes, Media strategy.

Forster, D 2013. EXPOSED 2013 Event in Cape Town Marks Beginning of Public Action Against Corruption, WEA News [Online]. Available: http://www.worldea.org/news/4192/ [2014, April 22].

Gooder, P 2014 .Thirty pieces of silver: An exploration of corruption, bribery, transparency and justice in the Christian Scriptures. London: Bible Society.

Gordon, G 2002. What If You Got Involved? Taking a Stand Against Social Injustice. Cumbria: Paternoster Press

Hara, N \& Huang, B-Y 2011. Online social movements. Annual review of information science and technology, 45(1):489-522.

Hauerwas, S 2014. Approaching the End: Eschatological Reflection on Church, Politics and Life. London: SCM Press.

Jackson, A 2014a. EXPOSED: Blog. 18 Australian ambassadors to receive letters ahead of G20 [Online]. Available: http://www.exposedcampaign.com/ blog/76 [2014, April 16].

Jackson A 2014b. EXPOSED: Blog. Benin: A Church without corruption for a more just nation is possible [Online]. Available: http://www.exposedcampaign.com/blog/70 [2014, April 16].

Jackson, A, Baker, T \& Forster, DA 2012. EXPOSED Policy and Campaign overview. Unpublished minutes.

Jenkins, P 2011. The Next Christendom: The Coming of Global Christianity. Oxford: Oxford University Press.

KC, T 2014. EXPOSED: Blog. Nepal: One voice, powerful witness [Online]. Available: http://www.exposedcampaign.com/blog/67 [2014, April 14]. 
Korten, D 1990. Getting to the $21^{\text {st }}$ Century: Voluntary Action and the Global Agenda. Hartford: Kumarian Press

Korten, D 1995. When Corporations Rule the World. Hartford: Kumarian Press.

MacMillan, C 2013. EXPOSED: Blog. Ninety gather in Toronto to pray for an end to corruption [Online]. Available: http://www.exposedcampaign.com/ blog/13 [2014, April 14].

Marsh, C 2008. The Beloved Community: How faith shapes social justice, from Civil Rights Movement to today. New York: Basic Books.

Micah Challenge: 10.10.10. 2010. Micah Challenge: 10.10.10 [Online] Available: http://www.micahchallenge.org/campaigns/20 [2014, April 16].

Moltmann, J 2006. The Politics of Discipleship and Discipleship in Politics: Jurgen Moltmann Lectures in Dialogue with Mennonite Scholars. Eugene, OR: Wipf and Stock Publishers.

Palmer, MD \& Burgess, SM 2012. The Wiley-Blackwell Companion to Religion and Social Justice. Hoboken, NJ: John Wiley \& Sons.

Stewart, C 2014. EXPOSED: Blog. 1000 join procession of witness in Cape Town [Online]. Available: http://www.exposedcampaign.com/blog/81 [2014, April 24].

Swart, I \& Venter, D 2002. Anti-Globalisation Organisation as a Fourth Generation People's Movement. Society in Transition. 33(1): 50-75.

Swart, I 2006. The Churches and the Development Debate: Perspectives on a Fourth Generation Approach. Stellenbosch: Sun Press.

Turner, E 2013. New Social Movements, Digital Revolution and Social Movements Theory. Peace Review: A Journal of Social Justice, 25(3): 376-383, DOI 10.1080/1042659.2013.816562.

Wallis, J 2006. God's Politics: Why the Right Gets it Wrong and the Left Doesn't Get it. Oxford: Lion Books. 
World Council of Churches. 2013. WCC calls churches to speak against corruption [Online]. Available: https://www.oikoumene.org/en/press-centre/ news/wcc-calls-churches-to-speak-against-corruption [2014, April 16]. 